\title{
PURA SIWA SILA GATRA PADANG BULIA, SUKASADA, BULELENG, BALI (SEJARAH, STRUKTUR DAN FUNGSI SERTA POTENSINYA SEBAGAI SUMBER BELAJAR SEJARAH LOKAL DI SMA)
}

\author{
Komang Gede Arya Bawa \\ SMA K Harapan Denpasar
}

e-mail:aryabawa87@gmail.com,

\begin{abstract}
ABSTRAK
Penelitian ini bertujuan untuk mengetahui: (1) sejarah berdirinya Pura Siwa Sila Gatra di Desa Padang Bulia, Sukasada, Buleleng, Bali, (2) struktur dan fungsi Pura Siwa Sila Gatra, dan (3)potensi yang terdapat di Pura Siwa Sila Gatra di Padang Bulia yang dapat dijadikan sumber belajar sejarah di SMA. Metode penelitian yang digunakan yaitu metode penelitin sejarah meliputi:(1) Pengumpulan data (heuristic) dengan Observasi, Wawancara, dan Studi dokumen. (2) Kritik Sumber. (3) Interpretasi dan (4) Historiografi. Hasil penelitian menujukkan bahwa: sejarah Pura Siwa Sila Gatra memiliki kaitan erat dengan ditaklukannya Tamblingan oleh Majapahit yang membuat masyarakat Tamblingan bermigrasi ke berbagai daerah. Struktur Pura Siwa Sila Gatra menggunakan konsep dwi mandala yaitu jeroan dan jaba sisi. Fungsi Pura Dalem Jawa yaitu (1) fungsi religius, (2) fungsi sosial, (3) fungsi ekonomi (4) fungsi hiburan, dan (5) fungsi pendidikan. Adapun potensi Pura Siwa Sila Gatra ialah aspek historis, aspek peninggalan meliputi pelinggih lontar, meru tumpang pitu, dan pendidikan karakter.
\end{abstract}

Kata Kunci: Sejarah, Pura Siwa Sila Gatra, Sumber Belajar Sejarah

\begin{abstract}
This study aims to determine: (1) the history of the establishment of Shiva Sila Gatra Temple in Padang Bulia Village, Sukasada, Buleleng, Bali, (2) the structure and function of Shiva Sila Gatra Temple, and (3) the potential contained in Siwa Sila Gatra Temple in Padang Bulia which can be used as a source of historical learning in high school. The research method used is the method of historical research including: (1) Data collection (heuristics) with Observation, Interviews, and Study documents. (2) Source Criticism. (3) Interpretation and (4) Historiography. The results of the study show that: the history of Siwa Sila Gatra Temple has a close connection with the conquest of Tamblingan by Majapahit which made the Tamblingan community migrate to various regions. Siwa Sila Gatra Temple structure uses two mandala concepts, inner temples and outer temples. The functions of the Siwa Sila Gatra Temple are (1) religious functions, (2) social functions, (3) economic functions (4) entertainment functions, and (5) educational functions. The potential of Shiva Sila Gatra Temple is a historical aspect, inheritance aspects include pelinggih lontar, meru tumpang pitu, and character education.
\end{abstract}

Keywords: history, Siwa Sila Gatra Temple, a source of learning history 


\section{Pendahuluan}

Pura merupakan istilah yang digunakan untuk menyebut tempat ibadah bagi Umah Hindu di Bali. Keberadaan Pura di Bali yang begitu banyak lengkap dengan keunikankunikannya yang khas dan memiliki ciri tersendiri. Keunikan tersebut dapat diamati dari segi bangunan, tempat, proses ritual, aura spiritual, dan sebagainya (Wiana, 2007:74). Pura di Bali yang teramat kemudian dikelompokan berdasarkan fungsinya menjadi 4 kelompokan yakni : Pura Kahyangan Jagat, Pura Kahyangan Desa, Pura Swagina dan Pura Kawitan (Ngurah. 1999: 177-178). Selain gambaran umum tentang pura yang dilihat berdasarkan fungsinya masih banyak pura di Bali yang tidak teridentifikasi berdasarkan pengelompokan tersebut.

Salah satunya ialah Pura Siwa Sila Gatra yang terletak di Desa Padang Bulia, kecamatan Sukasada, Kabupaten Buleleng. Keberadaan Pura Siwa Sila Gatra jika dilihat secara harafiah pura tersebut merupakan bentuk manifestasi terhadap pemujaan lontar, hal ini dapat dilihat dari adanya Keropak (tempat menyimpan lontar). Lontar sendiri merupakan perlambang dari adanya Ilmu Pengetahuan. Dalam kepercayaan Agama Hindu dewi yang di puja sebagai dewinya pengetahuan ialah Dewi Saraswati yang merupakan saktinya dari Dewa Brahma. Sehingga jika dilihat dari penamaanya Pura Siwa Sila Gatra akan menimbulkan pertanyaan mengapa harus menggunakan kata Siwa sementara saktinya dari Dewa Siwa ialah Durga atau Dewi Uma. Selain itu pada Pura ini juga sering dijadikan tempat untuk nunas tira untuk keperluan menyelenggarakan kegiatan upacara ritual keagamaan oleh masyarakat sekitar yang di pimpin oleh pemangku. Sedangkan umumnya, apa bila dalam menyelenggarakan upacara keagamaan (agama Hindu) di Bali biasanya mengundang para kaum brahmana yang dalam hal ini ialah seorang Pedanda. Situasi-situasi seperti itulah yang mengudang pertanyaan bagi penulis mengapa bisa demikian.Dari paparan di atas tampak bahwa Pura Siwa Sila Gatra memiliki ciri-ciri yang unik dan tersendiri serta berbeda dengan pura kebanyakan.

Tinjauan tentang Pura Siwa Sila Gatra, jika dikaitkan dengan proses pembelajaran sejarah pada kurikulum 2013, maka Pura Siwa Sila Gatra, beserta macam peninggalanpeninggalan yang ada di dalamnya dapat dimasukkan ke dalam Kompetensi Inti (KI 1 sd KI 4) pada silabus sejarah.

Kajian tentang pura sebagai sumber belajar sejarah sudah banyak dilakukan. Adapun kajian tersebut antara lain dilakukan oleh Kadek Aprianti (2015) Jro Kadek Mudiarta (2017), Gusti Made Sri Widiari (2018). Mengacu pada penelitian diatas terkait pura, penelitian tentang Pura Siwa Sila Gatra secara khusus belum ada yang melakukannya. Penelitian tetang Pura Siwa Sila Gatra dikaji dalam "Pura Siwa Sila Gatra Padang Bulia, Sukasada, Buleleng, Bali (Sejarah, Struktur dan Fungsi Serta Potensinya Sebagai Sumber Belajar Sejarah Lokal di SMA)". Berdasarkan latar belakang seperti yang telah disebutkan di atas, maka dapat dirumuskan permasalahan sebagai berikut:

1. Bagaimana sejarah Pura Siwa Sila Gatra di Desa Pakraman Padang Bulia, Buleleng, Bali ?

2. Bagaimana Fungsi Pura Siwa Sila Gatra di Desa Pakraman Padang Bulia, Buleleng, Bali ?

3. Apa Potensi Pura Siwa Sila Gatra sebagai sumber belajar sejarah lokal di SMA N 1 Sukasada?

Adapun tujuan yang hendak dicapai dalam penelitian ini antara lain:

1. Untuk mengetahui sejarah berdirinya Pura Siwa Sila Gatra yang ada di Desa Padang Bulia, Kecamatan Sukasada, Kabupaten Buleleng, Provinsi Bali.

2. Untuk mengetahui Funsi dari Pura Siwa Sila Gatra yang ada di Desa Padang Bulia, Kecamatan Sukasada, Kabupaten Buleleng, Provinsi Bali. 
3. Untuk mengetahui Potensi dari Pura Siwa Sila Gatra yang ada di Desa Padang Bulia, Kecamatan Sukasada, Kabupaten Buleleng, Provinsi Bali.

\section{Metode Penelitian}

Penelitian ini menggunakan pendekatan kulaitatif dengan mengunakan metotologi sejarah. Adapun langkah-langkah yang diambil dalam penelitian sejarah, yakni: (1.) Heuristik, ialah kegiatan penghimpunan sumber-sumber sejarah; (2.) Kritik, ialah meneliti apakah sumber-sumber itu sejati, baik bentuk maupun isinya; (3.) Interpretasi, untuk menetapkan makna dan saing-hubungan dari fakta-fakta yang telah diverifikasi; (4.) Historiografi, penyajian hasil sintesis yang diperoleh dalam bentuk kisah sejarah (Pageh, 2010; Daliman, 2015).

\section{Hasil dan Pembahasan}

Pura sebagai tempat suci khususnya bagi umah Hindu, adalah tempat berstananya dewa dan juga sebagai stana roh leluhur yang telah didewakan (Siddhidewata) dari kelompok atau soroh tertentu berdasarkan genelogis khususnya keluarga luas (Suyasa. 2006: 93). Dalam penelitian ini pura yang menjadi objek penelitian adalah Pura Siwa Sila Gatra yang terletak di Desa Padang Bulia, Kecamatan Sukasada, Kabupaten Buleleng, Bali. Keberadaan Pura Siwa Sila Gatra memang sangat sulit untuk di ungkapkan karena keterbatasan sumber data yang tertulis. Tetapi melihat dari fenomena yang ada di Desa Padang Bulia, maka kemungkinan kemungkinan keberadaan Pura Siwa Sila Gatra dapat diklasifikasikan menjadi 2 yaitu :

\section{Bentuk Penghayatan Pura "Siwa" (Penyiwaan) Dalem Tamblingan}

Melihat dari sejarah Desa Padang Bulia bahwa sebagian besar masyarakat Desa Padang Bulia merupakan yang merupakan bagian dari Tamblingan (fenomenanya terdapat soroh Dalem Tamblingan).

Dalam sejarahnya, Gajah Mada pada upacara pengangkatannya menjadi Patih Amangkubhumi Majapahit tahun 1258 Saka
(1336 M) mengucap sumpah untuk menyatukan nusantara. Bali (kerajaan Bedulu) yang menjadi salah satu daerah terdekat dari kerajaan Majapahit menjadi objek penaklukanya. Sebelum Sampai ke Bedulu, Tamblingan menjadi target penyerangan. Mengingat di daerah tersebut menjadi pusat pembuatan senjata pada masa itu. Dengan diserangnya wilayah Tamblingan maka masyarakat tamblingan dengan berbagai kelompok masyarakat menyebar ke berbagai wilayah, salah satunya ke Desa Padang Bulia.

Mungkin saja kelompok masyarakat Tamblingan yang ada di Desa Padang Bulia ini datang ketika hancurnya wilayah Tamblingan oleh serangan Majapahit. Mengingat situasi dan kondisi yang seperti itu, sebagaimana pada umumnya umat Hindu di Bali yang tidak mau terjadi keterputusan hubungan dengan tempat suci yang dipuja dan disakralkan. Di daerah Tamblingan terdapa juga Pura "Penyiwaan" Dalem Tamblingan yang menstanakan Ida Dukuh Sakti yang diSiwakan. Maka dibuatkanlah tempat suci untuk menyungsung Pura Siwa di dalem Tamblingan. Hal ini mungkin untuk memudahkan dalam ritual yang dilakukan di Tamblingan. Hal ini tak bisa dilepaskan akan adanya kenyataan bahwa pada abad ke-10 di wilayah Tamblingan setidaknya sudah terdapat kelompok sekta dengan masingmaising dewanya. Keberadaan sekta Siwa di Tamblingan di tecetuskan dalam prasasti Tamblingan Pura Endek II (tanpa berangka tahun) yang salah satunya menyebutkan terdapat Jumpung (kelompok) Siwa, disamping jumping waisnawa, brahmanisme, dan pande (Tim penyusun. 2007).

\section{Kedatangan tokoh spiritual ke Desa Padang Bulia.}

Pendirian Pura "Siwa" Sila Gatra yang juga diyakini merupakan jejak-jejak tokoh spiritual yang suci yang pernah datang ke daerah ini. Kedatangan tokoh ini meninggalkan jejakjejak tempat yang masih ada hingga saat ini, setiap tempat yang dijadikan sebagai tempat tapa brata yoga semadi dan dijadikan lokasi beliau, akan dibangunkan tempat suci. Salah 
satu tempatnya ialah di Pura Penyiwaan Dukuh Sakti Sila Gatra.

Pura Dukuh Siwa Sila Gatra diyakini sebagai tempat Ida Dukuh Sakti mencapai moksa dalam tapa brata yoga semadi. Tempat ini diyakini dulunya menjadi pusat perdukuhan/pasraman, sehingga banyak masyarakat yang juga belajar ke daerah tersebut. Hal ini dapat dilihat dari fenomena sekarang yang secara kenyataanya, bahwa bukan saja hanya pengempon yang bersembahyang kesana, melainkan juga orang lain yang dianggap memiliki hutang budi terhadap (Ida Dukuh Sakti). Kedatangan tokoh spiritual suci ini di ikuti dengan mendirikan padukuhan/pasraman atau pusat pembelajaran keagamaan pada masa itu. Beliau banyak menghasilkan karya-karya suci dalam bentuk lontar.

Ida Dukuh Sakti juga diyakini sebagai seorang sastrawan yang gemar membuat lontar maupun tembaga bertulis atau prasasti yang di hasilkan dari kegiatan tapa brata yoga semadi dan selama perjalanannya, namun hasil karya beliau telah tiada dan hanya menyisakan tempat penyimpanan lontar (Keropak). Ketidakadaan lonter tersebut tidak dapat dilepaskan dari dikuasainya seluruh Bali oleh Belanda tahun 1908. Belanda yang tertarik dengan karya-karya lontar di Bali termasuk karya Ida Dukuh Sakti membangun sebuah tempat yang di beri nama Gedong Kertya. Di sinilah karya-karya lontar di Bali dikumpulkan.

\section{Struktur dan Fungsi Pura "Siwa" Sila Gatra}

Pada dasarnya pembagian struktur halaman Pura "Siwa" Sila Gatra sama seperti pura pada umumnya di Bali. Pura "Siwa" Sila Gatra merupakan pura yang menggunakan konsep Dwi Mandala yaitu pembagian halaman pura menjadi dua bagian yaitu Utama Mandala (Jeroan) dan Nista Mandala (Jaba Sisi). Konsep Dwi Mandala yang melambangkan alam atas (urdhah) dan alam bawah (adhah). Dari setiap halaman tentunya memiliki bangunan-bangunan dan pelinggih-pelinggih yang memiliki fungsi tersendiri.
Nista Mandala atau yang biasa disebut jaba sisi adalah bagian terluar dari arsitektur pura. Bagian ini merupakan bagian nista atau kurang sakral dari sebuah pura yang melambangkan alam bawah (adhaa). Pada halaman nista mandala Pura "Siwa" Sila Gatra Setiap orang dapat memasuki bagian ini. Bangunan yang terdapat pada halaman ini diantaranya: terdapat Bale Gong yang fungsinya biasanya dijadikan tempat pementasan berbagai kesenian yang bersifat sakral maupun profane di areal pura; Bale Paebat biasanya digunakan untuk sarana pembuatan upacara, atau pembuatan kawas dan mengolah daging babi yang sudah di potong menjadi sarana upacara di Pura "Siwa" Sila Gatra, Bale Pewaregan istilah lain dari pewaregan adalah dapur umum, merupakan tempat dimana umat memasak untuk kepentingan pemedek (umat yang datang dari jauh), juga termasuk pengayah dan disini juga tempat untuk membuat kawas makanan khas yang ada pada setiap piodalan di pura yang ada di Desa Padang Bulia. dan terdapat dua pelinggih Pengapit Lawang yang merupakan penjaga kori ataupun candi bentar yang berfungsi sebagai penjaga lawang. Berupa pelingih sebagai stana dari Bhatara Kalla atau Dewa Ganapati dengan bhiseka jaga-jaga yang bertugas sebagai pecalang

Untuk memasuki halaman utama mandala terdapat bangunan Kori Agung yang fungsinya ialah menghubungkan dengan halaman utama mandala atau jeroan yang merupakan areal suci pura dengan nista mandala. Kori agung tersebut hanya digunakan ketika ada pujawali di Pura Siwa Sila Gatra, sedangkan untuk para umat yang akan bersembahyang, dapat melalui pintu yang lebih kecil yang terletak di sebelah kanan dan kiri.

Utama Mandala/Jeroan adalah areal bagian dalam dan bagian yang paling suci dari sebuah pura. Karena pada bagian ini, terdapat sejumlah bangunan suci yang biasanya merupakan pelinggih pokok dari sebuah pura. Bangunan suci yang utama pada Pura Siwa Sila Gatra ialah Meru tumpang pitu atau meru tingkat 7 yang merupakan tempat berstananya Ida Dukuh Sakti. Selain itu juga 
terdapat bangunan seperti Bale Pedatengan yang memiliki asal kata datang yang secara niskala memiliki filosofis sebagai tempat penyambutan tamu Ida Dukuh Sakti. Namun saat piodalan tempat ini secara sekala digunakan sebagai tempat menaruh sarana upacara piodalan dan banten. Selain itu juga terdapat Tepas yang berfungsi sebagai tempat untuk menaruh pajegan. Dan bangunan yang paling utama ialah Meru tumpang pitu ini merupakan manifestasi terhadap pemujaan Ida Dukuh Sakti. Semakin banyak tingkat Meru biasanya menunjukkan semakin agung BhataraBhatari yang distanakan di Meru itu. Arwah suci para Raja biasanya distanakan dalam meru dengan tingkat sebelas, sedangkan arwah suci orang kedua dalam suatu kerajaan, misalnya Patih Agung, distanakan dalam meru bertingkat Sembilan dan Tuju (Suhardana, 2006:119). Jika dilihat dari dari jumlahnya, Maka jelas bahwa Arwah suci yang di stanakan di Pura Siwa Sila Gatra merupakan tokoh Suci. Secara mistik saktinya Ida Dukuh Sakti dapat di dalami dari Meru tumpang 7 karena ajaran kanda 4 dewa disimbulkan dalam hurup modre $(\mathrm{Sa}+\mathrm{Ba}+\mathrm{Ta}$ $+\mathrm{A}+\mathrm{I}+$ Ang $+\mathrm{Ah})$.

Bangunan selanjutnya ialah Bale Paruman/piayasan yang memiliki fungsi sebagai tempat untuk meletakan banten dan sarana upacara lainnya yang diletakan di atas bale yang sudah ada. Sementara di bawahnya dijadikan sebagai tempat berkumpul prejuru saat bersembahyang di Pura Siwa Sila Gatra. Namun secara niskala tempat ini dijadikan sebagai tempat paruman oleh Ida Dukuh Sakti. Bangunan suci lainnya yang dapat di temukan di halaman utama mandala Pura Siwa Sila Gatra ialah Pelinggih Lontar, Pelinggih ini dijadikan sebagai tempat untuk menyimpan keropak Lontar yang ada, mengingat Lontar yang merupakan isi dari keropak tersebut telah tidak ada, Dengan adanya Pelinggih Lontar ini merupakan bentuk perwujudan penghormatan terhadap hasil karya-karya dari Ida Dukuh Sakti. Pelinggih ini dijadikan sebagai tempat untuk menyimpan keropak lontar, mengingat lontar yang merupakan isi dari keropak tersebut telah tidak ada (hal ini tidak dapat dilepaskan dari kedatangan belanda yang diambil dan dikumpulkan di gedong kertya, hingga terjadi penyakcakan Lontar tahun 1965). Bangunan terakhir yang dapat di lihat dihalam ini ialah Bale Prejuru. Saat piodalan berlangsung Bale Prejuru ini dijadikan sebagai tempat untuk memberikan dana punia yang diberikan oleh pemedek.

Pura adalah tempat suci untuk memuja Sang Hyang Widhi Wasa dengan segala manifestasinya atau prabawanya serta memohon anugerah sehingga selalu diberikan keselamatan dan ketentraman lahir batin. Begitu halnya dengan Pura Siwa Sila Gatra yang juga merupakan pura yang digunakan untuk memuja Sang Hyang Widhi Wasa berserta dengan segala manifestasinya. Selain itu Pura Siwa Sila Gatra juga mempunyai beberapa fungsi antara lain: fungsi religius bertujuan untuk meningkatkan Sradha dan Bhakti umat Hindu khususnya bagi umat yang menjadi pengempon pura, maupun masyarakat umum yang bersembahyang ke pura ini. Persembahyangan besar dimana para pamedek tangkil umumnya dilakukan pada saat piodalan, fungsi social ini dapat dilihat pada saat persembahyangan khususnya saat piodalan berlangsung sebagai pemersatu umat dari berbagai tempat dan kelas social. Selain itu dengan adanya pura ini masyarakat yang memiliki beragam kesibukan sehingga jarang berinteraksi degan orang sekitar akan menbaur dan menjadi satu ketika mereka melakukan ngayah di pura. fungsi ekonomi dapat dilihat dari adanya perputaran ekonomi (uang) yang memberikan keutungan tersendiri bagi para pedagang yang mencoba peruntungan untuk mendapatkan penghasilan dari berdagang saat piodalan di Pura Siwa Sila Gatra. fungsi hiburan dapat dirasakan dari proses piodalan dimana banyak disuguhkan tari-tarian baik yang bersifat profan maupun sakral. Adapun tarian profane yang biasanya ditampilkan adalah tari Kebyar Duduk, Puspanjali, Sekar Jagat. Sementara untuk tarian sakral yang merupakan serangkaian dari upacara piodalan menampilkan tari Rejang Dewa, Rejang Renteng, Pendet. fungsi pendidikan dapat dilihat dari adanya 
transformasi nilai-nilai budaya dan tradisi yang terjadi di pura.

\section{Potensi Pura Siwa Sila Gatra Sebagai Sumber Belajar Sejarah di SMA}

Adapun potensi-pontensi yang dimiliki Pura Siwa Sila Gatra sebagai sumber belajar sejarah di SMA antara lain: 1. Aspek historis : dimana pendirian Pura Siwa Sila Gatra dilihat dari sejarahnya memiliki sejarah yang panjang dan berlika liku. Hal ini berkaitan dengan hijrahnya orang-orang Tamblingan ke berbagai daerah yang salah satunya ke Desa Padang Bulia dan yang juga di ikuti dengan kedatangan seorang tokoh spiritual suci. 2. Aspek peninggalan: Pada Pura Siwa Sila Gatra terdapat sebuah pelinggih Lontar yang menyimpan sebuah Keropak sebagai tempat penyimpanan lontar. Warisan budaya yang satu ini juga telah memberikan aura keluhuran dan mentransmisikan keunggulan pemikiran masyarakat Bali yang melahirkannya. Tradisi lontar di Bali memiliki perjalanan sejarah yang panjang dan umur yang tua seiring dengan nilainilai sejarah, agama, filsafat, pengobatan, sastra, dan ilmu pengetahuan tinggi lainnya. Selain itu juga terdapat bangunan suci yaitu meru tumpang pitu. Meru mengingatkan kita pada salah satu peninggalan megalitik yaitu Punden berundak, Pagoda dan di Bali meru dengan tumpangnya. 3. Aspek Pendidikan Karakter, berdasarkan identifikasi peneliti, maka beberapa nilai yang tercermin dalam Pura Siwa Sila Gatra adalah sebagai berikut: nilai religius; Nilai ini dapat diamati dari proses persembahyangan pada piodalan yang diselenggarakan setiap setahun sekali yaitu pada Anggar kasih nuju sasih ke tiga yang biasanya tepat pada bulan September. Selain itu persembahyangan juga dilakukan pada hari raya saraswati yaitu hari turunnya ilmu pengetahuan. Nilai toleransi; Nilai ini ditunjukan dari adanya sikap dan tindakan dalam menghargai perbedaan pendapat saat musyawarah yang bertujuan untuk memecahkan masalah yang berkaitan dengan Pura Siwa Sila Gatra. Nilai disiplin; nilai ini dapat diamati pada saat pemedek memasuki areal utama mandala yang secara teratur dan tertib memasuki areal pura. Selain itu juga dapat diamati dari sikap para pengempon pura yang bertugas saye melakukan tugasnya dengan baik dan sesuai dengan tugas yang di berikan. Nilai kerja keras yang dapat diamati pada saat piodalan akan banyak menguras tenaga baik dalam mempersiapkan berbagai sarana ritual banten dan segala kelengkapanya hingga proses dari piodalan dan samapai piodalan itu berlangsung. Namun dengan kebersamaan dan kerja keras semua dapat dilakukan dengan baik. Nilai tanggung jawab; Hal ini dapat dilihat dari tanggung jawab yang di emban para saye dalam menjalankan tugasya. Misalnya saye gong, saye kidung meski acaranya berlangsung lama bahkan dari pagi hingga menuju pagi, para saye dan seka tetap semangat mengikuti ritual dan melaksanakan tanggung jawabnya dalam menjalankan tugas hingga piodalan selesai.

\section{Kesimpulan}

Berdirinya Pura Siwa Sila Gatra diperkirakan berkaitan erat dengan kenyataan bahwa Desa Padang Bulia adalah bagian dari Tamblingan. Yang kemudian di ikuti oleh kedatangan tokoh spiritual suci Kedatangan tokoh ini meninggalkan jejak-jejak tempat yang masih ada hingga saat ini, setiap tempat yang dijadikan sebagai tempat tapa brata yoga semadi dan dijadikan lokasi beliau, akan dibangunkan tempat suci. Salah satu tempatnya ialah di Pura "Siwa" Sila Gatra. beliau mendirikan padukuhan/pasraman atau pusat pembelajaran keagamaan pada masa itu. Yang kemudian banyak menghasilkan karya-karya suci dalam bentuk lontar. Namun sekarang hanya tersisa wadah untuk menaruh lontar yang disebut keropak.

Belanda yang pernah menaklukan Bali secara keseluruhan pada tahun 1908, kemudian mendirikan Gedong Kertya pada tahun 1928 dengan maksud mengumpulkan karya-karya lontar di Bali termasuk karya Ida Dukuh Sakti. Disinilah karya-karya lontar di Bali dikumpulkan kemudian dipilah yang bagus diperkirakan dibawa ke Belanda.

Struktur Pura "Siwa" Sila Gatra menggunakan konsep Dwi Mandala, terdapat 
dua jaba sisi atau Nista Mandala yaitu disebelah Utara dan jeroan atau Utama Mandala di sebelah selatan. Pada bagian nista mandala terdapat beberapa bangunan dan pelinggih seperti bangunan Bale Gong, Bale Paebat, Bale Pewaregan dan terdapat dua pelinggih Pengapit Lawang. Sementara pada halaman utama mandala terdapat beberapa bangunan suci, bangunan suci yang utama ialah Meru tumpang pitu atau meru tingkat 7 yang merupakan tempat berstananya Dewa Siwa (Ida Dukuh Sakti). Selain itu juga terdapat bangunan seperti Bale Pedatengan, Tepas, Penyawangan, Bale Piyasan, Pelinggih Lontar dan Bale Prajuru

Pura Siwa Sila Gatra mempunyai beberapai fungsi antara lain: fungsi religus, fungsi sosial, fungsi ekonomi, fungsi hiburan, dan fungsi pendidikan. Selain pendidikan nonformal, Pura "Siwa" Sila Gatra memiliki pontesi untuk menunjang pendidikan formal dengan memperhatikan aspek historis dari Pura "Siwa" Sila Gatra dan berbagai benda peninggalan berbudaya seperti Meru dan kropak lontar serta nilai-nilai nilai karakter yang dapat dijadikan sumber belajar sejarah di SMA

\section{Saran}

Berdasarkan hasil penelitian yang dilakukan, ada beberapa hal yang penulis sampaikan sebagai sumbangan saran terkait dengan hasil penelitian kepada beberapa pihak antara lain :

1. Masyarakat Desa Padang Bulia khususnya Pengempon Pura "Siwa" Sila Gatra bersama Pemerintah Kabupaten Buleleng diharapkan bersama-sama menjaga dan melestarikan Pura Siwa Sila Gatra sebagai salah satu pura kuno yang memiliki nilai historis yang sangat tinggi.

2. Peneliti lain yang ingin melanjutkan penelitian mengenai Pura Pura Siwa Sila Gatra, penelitian ini dapat dijadikan salah satu acuan penelitiannya.

3. Guru, penelitian ini dapat dijadikan sumber belajar sejarah kontekstual di tingkat SMA, guna membangun daya kritis siswa terhadap bangunan bersejarah di sekitar siswa.
4. Siswa, siswa lebih kritis dan peka terhadap bangunan bersejarah yang ada di sekitarnya sehingga bisa menghargai kearifan lokal yang ada dengan demikian hati siswa dapat tergugah untuk menjaga dan melestarikan Pura "Siwa" Sila Gatra sebagai salah satu bangunan bersejarah di Desa Padang Bulia

\section{Daftar Pustaka}

Daliman. 2015. Metode Penelitian Sejarah. Yogyakarta : Penerbit Ombak.

Ngurah, Gst. Made, dkk. 1999. Buku Pendidikan Agama Hindu Untuk Perguruan Tinggi. Surabaya: Paramita.

Pageh, I Made. 2010. Metodologi Sejarah Dalam Perspektif Pendidikan. Denpasar : FIS dan Pustaka Larasan.

Suhardana. (2006), Pengantar Etika dan Moralitas Hindu, Paramita, Denpasar.

Suyasa, Wayan. 2006. Pura Dasar Bwana Gelgel : Suatu Kajian Antropologi Politik. Jurnal Candra Sangkala. (edisi no. 8. Th. 18 Januari 2006).: 93-106.

Tim Penyususn. 2007. Situs amblingan. Dinas kebudayaan dan pariwisata buleleng : Balai Arkeologi Denpasar.

Wiana, I Ketut. 2007. Tri Hita Karana Menurut Konsep Bali. Surabaya : Paramita. 